\title{
Comparison studies of propylene oxide addition to phenyloctadecanol and phenyloctadecanoic acid and the surface activity studies of their sulphated products
}

\author{
By M.H.M. Ahmed
}

\author{
Chemistry Department, Faculty of Science, Benha University, Benha-Egypt
}

\section{RESUMEN}

Estudio comparativo de la adición de óxido de propileno a feniloctadecanol y ácido feniloctadecanoico y estudio de la actividad superficial de sus derivados sulfatados.

Se ha obtenido feniloctadecanol y àcido fenloctadecanoico via reacción catalizada acido de Lewis a partir de benceno y alcohol cieilico $\left(60^{\circ} \mathrm{C}\right)$ o ácido oleico $\left(80^{\circ} \mathrm{C}\right)$ respectivarnente. Se ha llevado a cabo un estudio comparativo por adición de Cxido de prcpleno a ambces sustratos en presencia de base (KOH) y ácido de Lews (SoCle) como catalizadores. Se encontró que la hidrooi. proplación de ambos sustratos a baja temperatura mediante ca. tálisis acido de Lewis es preferible a la catalisis bajsica. Se doterminó la actividad superficial de los productos sulfatados. Los resultados mostraron que las muestras producidas a partir de al. cohol (feniloctadecanol) tenian una mejor actividad superficial que las producidas a partir de ácido (ácido fenloctadecanoico). Por otro lado, las muestras peoducidas a partir de ambos sustra. tos utilizando catalizador dicido de Lewis tuvieron una actividad superticial mejor que las producidas con catalisis básica.

PALABRAS-CLAVE: Ácido fenvoctadecanoico - Actividad SLparficlal - Feniloctadecand - Hidrouipropilacion - Sulfatacion.

\section{SUMMARY}

Comparison studies of propylene oxide addition to phenyloctadecanol and phenyloctadecanoic acid and the surface activity studies of their sulphated products.

Phenyloctadecanol and phenyloctadecanoic acid were produced via Lewis acid catalyzed reaction of benzene and oloyl alcohol $\left(60^{\circ} \mathrm{C}\right)$ or oleic acid at $\left(80^{\circ} \mathrm{C}\right)$ respectively. A comparison study was achieved for the addition of propylene oxide to both substrates in the presence of base ( $\mathrm{KOH}$ ) and Lawis acid (SbCls) catalysts. It was found that, the hydroxypropylation of both substrates af low temperature via Lewis acid catalyst is more preterable than via the base catalyst. The surface activity of the sulphated peoducts was determined. The results revealed that the samples producod from alcohol (phenyloctadecanol) show a better surface activity than that from acid iphenyloctadecanoic acid). On the other hand the samples produced from both substrates using Lewis acid catalyst have a better surface activity than that produced with the base catalyst.

KEY-WORDS: Hydroxypropylation - Phenyloctadecanol Phanydoctadocanoic acid - Suphation - Surface activity

\section{INTRODUCTION}

Hydroxypropylation process is a reaction of propylene oxide with a compound containing active hydrogen.
$\mathrm{RXH}+\mathrm{CH}_{3} \mathrm{CH}-\mathrm{CH}_{2}$ catalyst $\mathrm{AXCH} \longrightarrow \mathrm{CH}\left(\mathrm{CH}_{3}\right) \mathrm{OH}$

where $\mathrm{XH}=\mathrm{OH}, \mathrm{COOH}, \mathrm{NH}$..........etc., and

$\mathrm{A}=$ long chain alkyl, aralkyl, alkyl phenol........etc.

The hydroxyalkylation process is most technological important process in the production of nonionic surfactant. The choice of proper substrate, average degree of hydroxypropylation and type of catalyst can be reached to "tailor moder. The tailor model is the compound produced according to its requested.

Since the hydroxypropylation reaction is a catalytic reaction [1], therefore it is largely affected by the type of catalyst used. The reactions of the fatty acid of alcohol with propylene oxide were reported [2-3]. The hydroxypropylated alcohol produced by the base catalyst is mainly monoester of propylene glycol [4].

The insertion of propylene oxide unit in the hydrophobic chain has benefits effect, prolongs the hydrophobic fragment of surfactants or modifies their surface active properties $[5,6]$. So the solubility of hydroxypropylated products is poor and can be sulphated to increase their solubility [3]. The purpose of this work is to investigate the addition of propylene oxide to phenyloctadecanol and phenyloctadecanoic acid and study the influences of the catalysts on the surface active properties of the sulphated products. The sequence of the reaction was shown in Scheme 1. The results were studied from two points of view:

1) Addition of propylene oxide to the two substrates in the presence of base and acid catalysts.

2) Studies of the surface activity of their sulphated products.

\section{EXPERIMENTAL}

\subsection{Preparation of phenyloctadecanol and phenyloctadecanoic acid $[7,8]$}

Oleyl alcohol or oleic acid (1 mole) was mixed with benzene ( 6 mole) and the reaction mixture was 


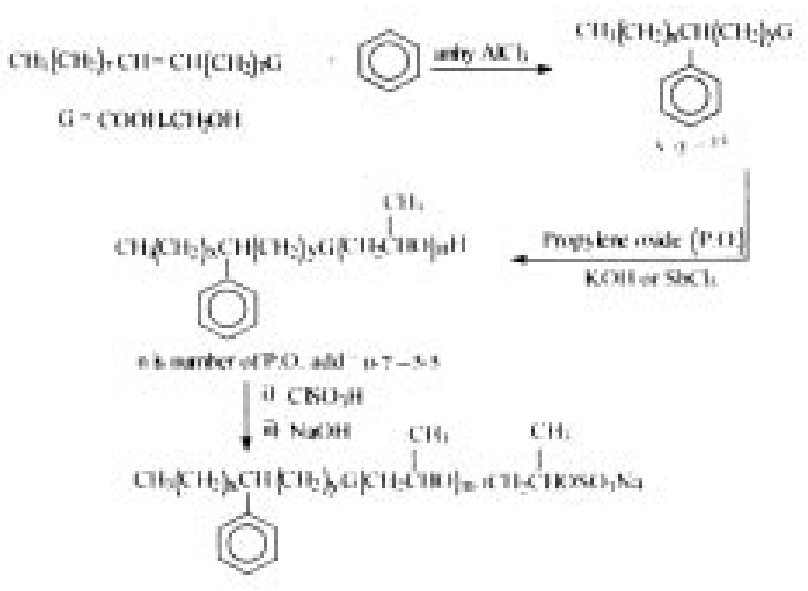

Scheme 1

stirred and heated $\left(60^{\circ} \mathrm{C}\right.$ in case of oleyl alcohol and $80^{\circ} \mathrm{C}$ in case of oleic acid) then anhydrous $\mathrm{AlCl}_{3}$ (1 mole) was added in small portions through one hour. After complete addition of the catalyst, the reaction mixture was stirred for an additional one hour, then poured into (ice $\mathrm{HCl} / \mathrm{H}_{2} \mathrm{O}$ ), extracted with chloroform, the solvent was distilled off (under vacuum) and the crude product was obtained (ct. Table I),

\subsection{Synthesis of propylene oxide adducts}

The hydroxypropylation was performed with the different catalysts, (they were applied in homogeneous phase): one is $\mathrm{KOH}$ and other is $\mathrm{SbCl}$ -

\section{Base catalyst}

The hydroxypropylation was done as described in reference [9]. The number of propylene oxide mole added to one mole of the starting materials was calculated by method similar to that described in [10].

\section{Lewis acid catalyst}

The hydroxypropylation was completed as described in reference [11], In an ice cooled $250 \mathrm{ml}$ round flask fitted with a reflux condenser and magnetic stirrer calculated starting material and catalyst was

Table I

\section{Characteristic parameters of the products}

\begin{tabular}{|c|c|c|c|}
\hline Product & $\underset{\%}{\text { Yield }}$ & Boiling point & $\begin{array}{c}\text { Characteristic } \\
\text { state }\end{array}$ \\
\hline phenyloctacecand & 69 & $186-194 \mathrm{bas}[7]$ & $\begin{array}{c}\text { viscous colourless } \\
\text { of }\end{array}$ \\
\hline $\begin{array}{c}\text { Phenyloctadecanoic } \\
\text { acid }\end{array}$ & 65 & $217.223 \mathrm{~b}_{4}[\mathrm{~B}]$ & brown viscous of \\
\hline
\end{tabular}

Table II Reaction condition of hydroxypropylation process

\begin{tabular}{|c|c|c|c|c|}
\hline \multirow{2}{*}{ Substrate } & \multicolumn{2}{|c|}{ Catalysts } & \multirow{2}{*}{$\begin{array}{l}\text { Reaction } \\
\text { temp. } \mathrm{C}\end{array}$} & \multirow{2}{*}{$A D P$} \\
\hline & type & cone (mol \%) & & \\
\hline Phenyloctadecanol & $\begin{array}{l}\mathrm{KOH} \\
\mathrm{SbCl}\end{array}$ & $\begin{array}{l}0.01-10 \\
0.01-10 \\
\end{array}$ & $\begin{array}{c}50-120 \\
30-60\end{array}$ & $\begin{array}{l}0.5 .53 \\
0.7 .63 \\
\end{array}$ \\
\hline $\begin{array}{l}\text { Pheryloctadecanoic } \\
\text { acid }\end{array}$ & $\begin{array}{l}\mathrm{NOH} \\
\mathrm{SbCl}\end{array}$ & $\begin{array}{l}0.01-10 \\
0.01-10\end{array}$ & $\begin{array}{l}50-120 \\
30-60\end{array}$ & $\begin{array}{l}0.7 .52 \\
0.7 .50\end{array}$ \\
\hline
\end{tabular}

ADP: average degree of hydroxypropylation [10]

placed and the appropriated amount of propylene oxide was dropped. The desired temperature was achieved using thermostat, until the reaction complete. The unreacted propylene oxide was removed in vacuum. The mole of propylene oxide added was determined as maintained above (ct. Table II).

\subsection{Synthesis of polyhydroxypropylated alcohol sulphates}

\section{Sulphation}

It was completed as described in [6]. A typical procedure was: Hydroxypropylated alcohol $(0.1$ mole) was dissolved into $100 \mathrm{ml}$ of $\mathrm{CCl}_{4}$, cooled, vigorously stirred and 10 mole $\%$ of chlorosulphonic acid was slowly dropped into the reaction mixture at a rate that the temperature remained below $5^{\circ} \mathrm{C}$. After one hour of the stirring equal volume of cooled methanol was slowly added, the reaction mixture was neutralized with $40 \%$ aqueous $\mathrm{NaOH}$ at $0^{\circ} \mathrm{C}$. After 2 hours the solvent was distilled off; the final product was purified by dissolving several time into a hot mixture of methanol isopropanol.

\section{${ }^{1}$ HNMR analysis}

Nuclear magnetic resonance spectra were recorded on a Varian EM-390 spectrometer operating at $90 \mathrm{MHz}$. Deutero-chloroform was used as solvent and tetramethyl silane as internal standard. Chemical shifts are reported as (ppm) relative to tetramethyl silane.

\section{Determination of the performance properties}

\section{The surface and interfacial tensions}

The crude oily of the prepared compounds were used for the measurements in aqueous phase. The surface and intertacial tensions were measured with different surfactants concentrations at room temperature $\left(25^{\circ} \mathrm{C}\right)$ using a Du-Nouy tensiometer (Kruss, type 8451) [12]. The cmc (critical micelle concentration) was determined by intersection in the curve of a relationship between surface tension ( $\delta$ ) and $\log [\mathrm{c}]$. 


\section{Kraft point}

Kraft point of the prepared surfactants was easured as the temperature at which 1 wt $\%$ spersion becomes clear on gradual heating [13].

\section{Wetting time}

Was determined by immersing a sample of cotton bric in 1 wt \% aqueous solution of the surfactants [14].

\section{Foaming height}

Was measured according to [15]. A $25 \mathrm{ml}$ solution $.0 \mathrm{wt} \%$ ) was shaken vigorously for 10 seconds in a $0 \mathrm{ml}$ glass stoppered, graduated cylinder. The lution was allowed to stand for 30 seconds, and foam height was measured.

\section{Emulsion stability}

The emulsion was prepared from $10 \mathrm{ml}$ of a 20 nol aqueous solution of surfactant and $5 \mathrm{ml}$ of uene at $40^{\circ} \mathrm{C}$. The emulsifying property was termined by the time it took for an aqueous volume parating from the emulsion layer to reach $9 \mathrm{ml}$ unting from the moment of the cession shaking [16].

\section{RESULTS AND DISCUSSION}

Preparation of starting materials: It was done in od yields according to $[7,8]$ by Friedel-Crafts cylation of oleyl alcohol or oleic acid to dry benzene the presence of anhydrous $\mathrm{AlCl}_{3}$. The aracterization of the products is shown in Table $\mathrm{L}$. e products were mixture of isomers (in case of ic acid, there are 12 positions isomers with phenyl oup at position 6-17 on the fatty acid chain [17], but in oleyl alcohol there are 5-phenyl isomer (at sition 8-13 on the fatty alcohol chain) and a aller amount of 17-phenyl isomer were formed [7]. e main isomers for both substrates are 9, 10 enyl isomers.

\subsection{Hydroxypropylation of the starting materials}

It was carried out in homogeneous medium by ing base catalyst $(\mathrm{KOH})$ [9] and $\mathrm{SbCl}_{5}$ [11]. The duced hydroxypropylated compounds were in the ge 0.5-6.3 propylene oxide units (ct. Table II). The aracteristic 'HNMR bands for the produced droxypropylated compounds was $\delta=3.2-4.1[\mathrm{~m}$, $\left.\mathrm{I}_{2} \mathrm{CH}\left(\mathrm{CH}_{3}\right) \mathrm{O}\right]$ and $\mathrm{IR}$ wagging vibration of $\delta_{\mathrm{S}} \mathrm{CH}_{3}$ of pylene glycol unit at $1376 \mathrm{~cm}^{-1}[18]$.

\subsection{Hydroxypropylation studies}

The hydroxypropylation was investigated at erent temperature and catalyst concentration, the
Table III

Reaction velocity of hydroxypropylated phenyloctadecanoic acid and alcohol

\begin{tabular}{cccc}
\hline $\begin{array}{c}\text { Catalyst } \\
\text { concentration }\end{array}$ & $\begin{array}{c}\text { Aeid } \\
\left(W .10^{*}\right)\end{array}$ & $\begin{array}{c}\text { Alcohol } \\
\left(W .10^{2}\right)\end{array}$ & $\begin{array}{c}\text { Temperature } \\
(\mathrm{C})\end{array}$ \\
\hline $\mathrm{KOH}, 8.91$ mole $\%$ & $1.34^{*}$ & $3.86^{*}$ & 120 \\
& $0.15^{* *}$ & $0.44^{* *}$ & \\
\hline $\mathrm{SoCl} 5$ mole \% & $3.06^{*}$ & $5.74^{*}$ & 50 \\
& $0.612^{* *}$ & $1.15^{* *}$ & \\
\hline
\end{tabular}

-ADP/min, "ADP/min. mole catalysts and $(W)$ is virtual fate of hydroxypropylation.

results are tabulated (ct. Table III). The average degree of hydroxypropylation was plotted as function of the reaction time at a constant catalyst concentration and reaction temperature. The virtual reaction rate $(W)$ was taken as the slope of the linear relationship, the results given in Table III. The alcohol shows rate approximately three time faster than the acid. Also in the both substrates the $\mathrm{SbCl}_{5}$ shows a higher rate than $\mathrm{KOH}$.

\subsection{Sulphation}

Sulphation of the products was done in good yields by method similar to that described in [6]. The disappearance of $\mathrm{OH}$ of propylene glycol in the IR spectra was recorded.

\subsection{Surface activity}

The surface properties of the sulphated products were investigated and the effect of the propylene glycol units on the surface properties has been clarified.

\section{Surface and interfacial tension}

Were measured at $1 \mathrm{wt} \%$ surfactant concentration; the results are given in Table IV and V. The propylene glycol units has effect on the surface activity; as the number of propylene glycol increases [1.0 to 5.3], the surface tension of sulphated alcohol was increased from 33.0 to $46.3 \mathrm{mN} / \mathrm{m}$ and for the sulphated acid from 35.3 to $49.8 \mathrm{mN} / \mathrm{m}$. The effect of the catalyst on the surface activity of the prepared sulphated compound was shown from the determination of the cmc [19]. It was determined by plotting the surface tension [8] against log [c]; the values of cmc are shown in Table VI. The results of $\mathrm{cmc}$ for the hydroxypropylated phenyloctadecanol sulphate produced from $\mathrm{SbCl}$ show a lower concentration and better surface activity in a comparison with that produced by $\mathrm{KOH}$ catalyst. The same tendency was observed for the hydroxypropylated phenyloctadecanoic acid sulphate. This can be attributed to the fact that the Lewis acid catalyst gave the narrow range distribution $[5,20]$. Moreover, the hydroxypropylated 
phenyloctadecanol sulphate produced from $\mathrm{KOH}$ shows a lower $\mathrm{cmc}$ and surface tension than that produced from hydroxypropylated phenyloctadecanoic sulphate by using the same catalyst. It is interesting to find a good relationship between surface tension at cmc and propylene oxide units in the study range of the prepared compounds, in which sulphated group has not any effect on the relationship but it depends on the propylene oxide units (ct. Fig. 1). The constants of the relationship are given in Table VII.

Table IV

Surface properties of hydroxypropylated phenyloctadecanol sulphate (alcohol, $\mathrm{KOH}$ )

\begin{tabular}{|c|c|c|c|c|c|c|c|c|}
\hline \multirow{2}{*}{ Sulphated products } & \multirow[t]{2}{*}{ n } & \multicolumn{2}{|c|}{$\begin{array}{l}\text { Surtace tension } \\
\text { mN/m, } 1 \text { wt \% }\end{array}$} & \multirow{2}{*}{$\begin{array}{c}\text { Interfacial } \\
\text { tension } \\
\text { mNNm } \\
1 \mathrm{wt} \\
\end{array}$} & \multirow{2}{*}{$\begin{array}{l}\text { Foum } \\
\text { height } \\
\text { (mm) } \\
1 \text { at } \%\end{array}$} & \multirow{2}{*}{$\begin{array}{l}\text { Kraft } \\
\text { point } \\
\varnothing \mathrm{C} \\
1 \mathrm{wt} \%\end{array}$} & \multirow{2}{*}{$\begin{array}{l}\text { Wetting } \\
\text { time } \\
\text { second } \\
1 \text { af } \%\end{array}$} & \multirow[t]{2}{*}{$\begin{array}{l}\text { Emulsion } \\
\text { min. }\end{array}$} \\
\hline & & $\mathrm{SbCl}_{4}^{*}$ & KOMr" & & & & & \\
\hline $\mathrm{CH}$. & 0.0 & 33.0 & 33.5 & 7.0 & 250 & 10 & 45 & 150 \\
\hline & 1.0 & 33.5 & 35.5 & B. 0 & 240 & 12 & 43 & 145 \\
\hline 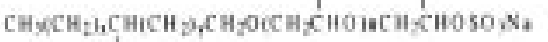 & 2.0 & 34.0 & 36.5 & 95 & 235 & 15 & 41 & 140 \\
\hline | & 3.0 & 35.0 & 42.0 & 11.0 & 230 & 17 & 39 & 135 \\
\hline 1 & 4.3 & 36.0 & 46.3 & 12.0 & 220 & 20 & 36 & 130 \\
\hline 4 & & & & & 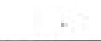 & & & \\
\hline
\end{tabular}

$x+y=15$, "lydroxypropylated sulphate produced via Lewis acid catalyst and

"that produced via base catalyst.

Errors of messurements were.

Surface and intertacial tensions $= \pm 0.1$ dymeskm.

Kratt point $\quad= \pm 10 \mathrm{C}$

Foem height $\quad= \pm 2 \mathrm{~mm}$

Wetting time $\quad= \pm 1 \mathrm{sec}$.

Emulsion $\quad= \pm 1 \mathrm{~min}$.

Table V

Surface properties of hydroxypropylated phenyloctadecanoic acid sulphate

\begin{tabular}{|c|c|c|c|c|c|c|c|c|}
\hline \multirow[t]{2}{*}{ Sulphate products } & \multirow[t]{2}{*}{$\mathbf{n}$} & \multicolumn{2}{|c|}{$\begin{array}{c}\text { Surtace tension } \\
m \mathrm{~m} / \mathrm{m}\end{array}$} & \multirow{2}{*}{$\begin{array}{c}\text { Inierfacial } \\
\text { tension } \\
m N / m \\
1 \text { wt } \%\end{array}$} & \multirow{2}{*}{$\begin{array}{l}\text { Foam } \\
\text { height } \\
\text { (mm) } \\
1 \mathrm{w} \%\end{array}$} & \multirow{2}{*}{$\begin{array}{c}\text { Kraft } \\
\text { point } \\
\text { c } \\
1 \text { wis os }\end{array}$} & \multirow{2}{*}{$\begin{array}{l}\text { Wetting } \\
\text { time } \\
\text { secend } \\
1 \text { wt } \%\end{array}$} & \multirow[t]{2}{*}{$\begin{array}{l}\text { Emulsien } \\
\text { min. }\end{array}$} \\
\hline & & $\mathrm{SbCl}_{1}{ }^{*}$ & $\mathrm{KOH}^{* *}$ & & & & & \\
\hline \multirow{6}{*}{$\mathrm{CHaCH} \mathrm{H}_{2} \mathrm{CH}$} & & & & & & & & \\
\hline & 0.0 & 33.5 & 35.3 & 8.0 & 230 & 14 & 49 & 140 \\
\hline & 1.0 & 34.0 & 36.8 & 9.0 & 220 & 13 & 46 & 135 \\
\hline & 2.0 & 35.5 & 43.2 & 11.0 & 215 & 15 & 44 & 130 \\
\hline & 3.0 & 37.5 & 46.2 & 12.0 & 210 & 17 & 41 & 125 \\
\hline & 4.2 & 41.5 & 49.8 & 14.0 & 200 & 18 & 40 & 125 \\
\hline
\end{tabular}

$x+y=15$, "hydroxypropylated sulphate produced via Lewis acid catalyst and

"that producod via base catalyst.

Errors of measurements were:

Surtace and intertacial tensions $= \pm 0.1$ dynes/cm

Kratt point

Foam height

Wetting time

$= \pm 1^{\circ} \mathrm{C}$

Emulsion

$= \pm 2 \mathrm{~mm}$

$= \pm 1 \sec$

$= \pm 1 \mathrm{~min}$.

\section{Foaming property}

The results are given in Table IV and V, indicating that the increase in the hydroxypropylene chain length causes a decrease in the foam height; the hydroxypropylated samples produced from acid substrate has lower foam height than that from alcohol for the same number of propylene oxide units [5].

\section{Wetting property}

The wetting time for hydroxypropylated phenyloctadecanol and for phenyloctadecanoic acid 
Table VI

$\mathrm{cmc}$ and $\delta$ (surface tension at $\mathrm{cmc}$ ) values for hydroxypropylated phenyloctadecanol and phenyloctadecanoic acid sulphate. The standard deviation of $\delta$ was found to be \pm 0.5

\begin{tabular}{|c|c|c|c|c|c|}
\hline$A P D$ & $\mathrm{eme}$ [molv] & {$\left[\begin{array}{l}(5) \\
{[\mathrm{mNm}]}\end{array}\right.$} & 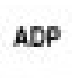 & $\begin{array}{l}\mathrm{eme} \\
\text { [molit] }\end{array}$ & $\begin{array}{c}\{5\} \\
{\left[\mathrm{mmN}^{2}\right]}\end{array}$ \\
\hline \multicolumn{6}{|c|}{ Hychorypropylated phenyloctadocanol sulphate } \\
\hline \multicolumn{3}{|c|}{$\mathrm{KOH}$} & & & \\
\hline $\begin{array}{l}1.0 \\
2.0 \\
3.0 \\
4.0 \\
\end{array}$ & $\begin{array}{l}0.0193 \\
0.0237 \\
0.0272 \\
0.0372\end{array}$ & $\begin{array}{l}34.63 \\
35.90 \\
37.83 \\
38.87\end{array}$ & $\begin{array}{l}0.9 \\
2.0 \\
3.0 \\
4.0\end{array}$ & $\begin{array}{l}0.0182 \\
0.0205 \\
0.0253 \\
0.0308\end{array}$ & $\begin{array}{l}33.85 \\
34.70 \\
36.52 \\
38.05\end{array}$ \\
\hline \multicolumn{6}{|c|}{ Hydroxypropylated phemyloctadecanoic acid sulphate $[\mathrm{KOH}]$} \\
\hline \multicolumn{3}{|c|}{$\mathrm{KOH}$} & & & \\
\hline $\begin{array}{l}2.0 \\
3.0 \\
4.0\end{array}$ & $\begin{array}{l}0.028 \\
0.0329 \\
0.0392\end{array}$ & $\begin{array}{l}37.10 \\
38.60 \\
39.76\end{array}$ & $\begin{array}{l}2.0 \\
3.0 \\
4.0\end{array}$ & $\begin{array}{l}0.0261 \\
0.0275 \\
0.0324\end{array}$ & $\begin{array}{l}35.43 \\
37.14 \\
38.56\end{array}$ \\
\hline
\end{tabular}

Table VII

Constants of the relationship of propylene oxide units and $\delta$ surface tension at cmc for the prepared sulphated compounds

\begin{tabular}{lccccc}
\hline $\begin{array}{c}\text { Hydroxypropyl } \\
\text { Sulphaled Compounds }\end{array}$ & Catalyst & a & S & sD & I \\
\hline Phenyloctadecanol & $\mathrm{KOH}$ & 0.993 & 1.465 & 0.258 & 33.145 \\
\hline Phenytoctadecanol & $\mathrm{SbCl}$ & 0.990 & 1.442 & 0.312 & 32.175 \\
\hline Pheryloctadecanoic & $\mathrm{KOH}$ & 0.997 & 1.390 & 0.138 & 34.497 \\
\hline Pheryloctadecanoic & $\mathrm{S6Cl} 5$ & 0.998 & 1.565 & 0.118 & 32.450 \\
\hline
\end{tabular}

(ब) is correlation coefficient, (S) is slope; (SO) is standard deviaton; and (I) is intersection

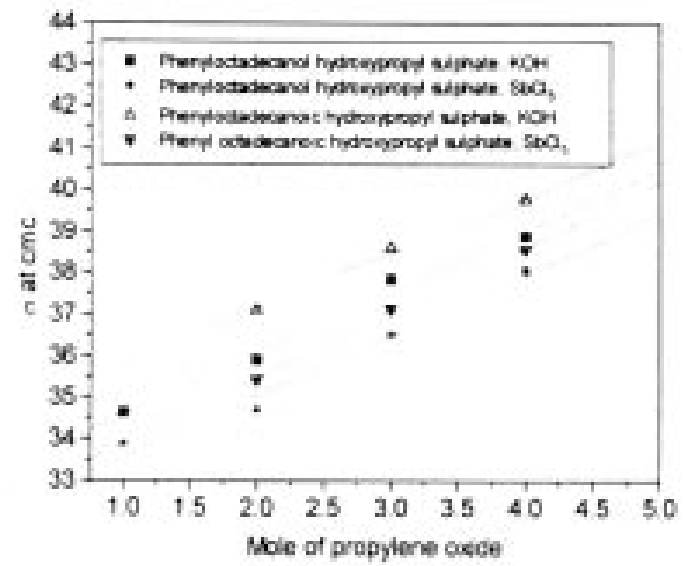

Figure 1

Relationship between mole of propylene coide and surface tension at cme for prepared hydroxypropyl sulphated compounds. sulphate has the same tendency (Tables IV and V). When increasing the number of hydroxypropylene unit in the molecule, the wetting time was decreased; this means that, the propylene unit inserted in the molecule has an effect on this property. The presence of hydroxypropylene units improves the wetting of aqueous solutions of these compounds [3].

\section{Kraft point and emulsion properties}

For both of the hydroxypropylated compared compounds, the Kraft point has the same tendency (Tables IV and V). It was increased by increasing the number of propylene oxide units in the molecules. The reverse trend was obtained for the emulsion property [21].

\section{BIBLIOGRAPHY}

1. Schick, M.J. (1967). Nonionic surfactants. pp. 11. Edited by Marcel Dekker, Inc., New York NY.

2. Chebicki, J. and Zwielka, A. (1990). The reaction of fatty acids and their derivatives with propylene coxide. Tenside Surt. Det. 27, 226-269.

3. Chebicki, J. and Slipko, K. (1980). Synthesis and surface activity of sodium polyoxypropylated higher alcohol sulphates. Tenside Detergents, 17, 130-134.

4. Chebicki, J. and Zwiefka, A. (1985). The reaction of fatty acids and their derivatives with propylene oxide. Tonside Detergents, 22, 117-120.

5. Weil, J.K., Stirton, A.J. and Barr, E.A. (1966). Oxypropylation of fatty alcohols, and the sulfation products. J. Am. Oir Chem. Soc. 43, 157-160.

6. Chebicki, J. (1990). Polyoxypropylated alkylphenol sulphates. Tenside Surf Det. 27, 413-416.

7. Smith, F.D., Stirton, A.T. and Nuñez-Ponzoa, M.V (1997). Phenyloctadecanol and surface active derivatives. J. Am. OVI Chem. Soc. 44, 413-415.

B. Stirton, A.J., Schaefler, B.B., Stawitzke, Anna A., Weil, J.K. and Waldo C. Altult. (1948). Arylstearic acids from oleic acid. Variables affecting the yield and properties. $J$ Am. Oir Chemists Sac. 25, 365.

9. El-Sawy, A.A., Mahmoud, A.A, and Shaker, N.O (1990). Preparation and surlace active properties of oxypropylated diol monoesters of fatty acids. J. Serb. Chem. Soc. 55, 395-400.

10. Ahmed, M.M.H., Sallay, P. Rusznak, I. and Farkas, L. (1996). Determination of the average ethoxylation degree. Tenside Surt. Dot. 33, 410-411.

11. Herczeg, L., Morgós, J., Sallay, P., Farkas, L., Rusznák, I. (1981). Examination of reactions on hydroxypropylation Kolor Ërt. 4, 144-151.

12. Chen, K.M. and Wang, H.R. (1992). Synthesis and surface activity of sell-sequestering surfactants. J. Am. Oil Chemists Soc. 69, 60-63.

13. Daisuke, O., Arki, M., Yohji, N., Mitsuo, O., Shingo, Y. and Tokuji, T. (1993). Preparation, surface-active properties and acid decomposition profiles of a new "soap" bearing a 1,3-dioxalane ring. J. Am. Oil Chemists. Soc. 70, 29-36.

14. Cohen, A.W. and Rosen, M.J. (1981). Wetting properties of nonionic surfactants of homogeneous structure. $J$. Am. ON Chemists Sac. (S\&D 212) 1062-1066.

15. Domingo, L. Fiquet and Meijer, H, (1992). Foam ability / stability of surlactants. Tenside Surf. Det. 29, 16-22. 
16. Takeshi," H. (1970). Studies of ester-containing surfactants. Preparation and properties of sodium sulloalkyl alkanoates. Bull. Chem. Soc. 43, 2236-2240.

17. Smith, F.D. Kenney, H.E. and Stirton, A.J. (1965) Isomeric arylstearic acids. J. Am. Olv Chem. Soc. 42, 885-888.

18. Meszlenyi, G., Sipos, M., Juasz, M., Eross-Lelkes and Poszmik, Gy (1988). Intrared spectroscopic of propylene oxide-ethylene oxide polymers. Acta Physica Hungarica, 63, 137-140.

19. Ahmed, M., Mate, M., Tolnai, Gy.. Horvolgyi, Z., Sallay, P. and Farkas, L. (1997). The interfacial of new types of hydroxyethylated alcohols. ACH-Modois in Chemistry, $134,721-734$.
20. Ahemd, M., Mate, M., Horvolgyi, Z., Sallay, P. and Farkas, L. (1997). The interfacial behaviour of polydisperse hydroxyethylated aralkyl alcohols: A surtace activity study. Proceeding of $7^{7}$ Conference on Colloid Chemistry, Eger, Hungary. pp. 209-212.

21. El-Sawy, A.A., Essawy, S.A., El-Sukkary, M.M. and Eissa, A.M.F. (1992). Surfactants from 2-hydroxy tatty acids I. Sulphation products of 2-hydroxy fatty acids, esters, diols and alkanolamines. Hungarian $\mathcal{J}$ of Industrial Chemistry, 20, 25-28.

Recibido: Mayo 2000 Aceptado. Junio 2001 